\title{
Blades and papillae as likely dispersing propagules in Chilean populations of Mastocarpus sp. (Rhodophyta, Gigartinales)
}

Láminas y papilas como posibles propágulos de dispersión en poblaciones chilenas de Mastocarpus sp. (Rhodophyta, Gigartinales)

\author{
Mauricio H. Oróstica ${ }^{1,2}$, Ricardo D. Otaíza ${ }^{3}$ and Paula E. Neill ${ }^{3}$ \\ ${ }^{1}$ Centro Regional de Investigación y Desarrollo Sustentable de Atacama (CRIDESAT) CONICYT-REGIONAL R06I1003, \\ Avda. Copayapu 485, Copiapó, Chile \\ ${ }^{2}$ Programa de Magíster Ciencias del Mar, Facultad de Ciencias del Mar, Universidad Católica del Norte, Avda. Larrondo 1281, \\ Coquimbo, Chile \\ ${ }^{3}$ Departamento de Ecología, Facultad de Ciencias, Universidad Católica de la Santísima Concepción, Concepción, Chile. \\ rotaiza@ucsc.cl
}

Resumen.- Mastocarpus sp. es un alga roja nativa a la costa del Pacífico de Norteamérica, y también presente en Concepción, Chile (ca. $\left.37^{\circ} \mathrm{S}\right)$, donde se ha propuesto como especie no indígena. Su establecimiento y expansión podrían verse favorecidos si láminas y papilas constituyeran propágulos. Las características de desprendimiento de estas dos estructuras apoyan esta interpretación. Láminas de Mastocarpus sp. requirieron menos fuerza para ser desprendidas desde las rocas que láminas de otras algas rojas comunes. Asimismo, un estimado mensual de $14,9 \%$ de las papilas con cistocarpos maduros se desprenden de láminas sometidas a turbulencia en laboratorio. Además, es común encontrar láminas y papilas a la deriva, y liberan esporas de pigmentación normal. La distribución de papilas a lo largo de las láminas, considerando su madurez, sugiere un patrón de desprendimiento predecible. Papilas nuevas fueron más abundantes en segmentos distales de láminas, y papilas viejas en segmentos centrales. La abundancia de cicatrices dejadas por papilas desprendidas fue mayor en segmentos basales, sugiriendo que las papilas que dejaron esas cicatrices portaban cistocarpos maduros. Concluimos que los puntos de adhesión de láminas y papilas se tornarían relativamente más débiles a medida que crecen, facilitando su desprendimiento. Esto no representa la abscisión de estructuras senescentes ya que en su interior crecen carpoesporofitos con esporas que pueden ser liberadas. Esto facilitaría el establecimiento de nuevos individuos a distancias y lugares diferentes de los que alcanzarían las esporas, pudiendo ser consideradas como estructuras alternativas de dispersión. Como tales, podrían afectar la dinámica poblacional y expansión de rango de Mastocarpus sp. en Chile.

Palabras clave: Desprendimiento, especie no indígena, estrategia de dispersión, fragmentos a la deriva, Phyllophoraceae

Abstract.- Mastocarpus sp. is a red macroalga native to the Pacific coast of North America, and present around Concepción, Chile ( $\left.\mathrm{ca} .37^{\circ} \mathrm{S}\right)$, where it has been suggested as a non-indigenous species. Its establishment and expansion could be favored if blades and papillae function as propagules. The characteristics of the detachment of these two structures support this interpretation. Blades of Mastocarpus sp. become detached from rocks more readily than other common, bladed red seaweeds. In turn, a monthly estimate of up to $14.9 \%$ of papillae carrying mature cystocarps easily broke off from blades when experimentally subjected to turbulence in the laboratory. Additionally, blades and papillae are commonly found drifting, and release normally pigmented spores. The distribution of papillae along the blades, considering their maturity, suggests a predictable detachment pattern. New papillae were more abundant on distal segments, old papillae on middle segments, and scars of shed papillae on basal segments, suggesting that shed papillae carried mature cystocarps. We conclude that blades and papillae have attachment points that become relatively weaker as they grow and mature, facilitating their detachment. This does not represent abscission of empty or senescent structures because carposporophytes growing inside these structures still carry spores that can be released. Thus, blades and papillae may be important in facilitating the establishment of new individuals at distances and places different from what is achieved by spores and, hence, could be considered as alternative dispersing entities. As such, they could affect the population dynamics and range expansion of Mastocarpus sp. in Chile.

Key words: Detachment, dislodgment, dispersal strategy, drifting fragments, non-indigenous species, Phyllophoraceae 


\section{INTRODUCTION}

For seaweeds, and other benthic organisms, dispersal is a fundamental process in maintaining and restoring local populations, and in the colonization of new environments (Santelices 1990, Reed et al. 2000, Kinlan \& Gaines 2003, Shanks et al. 2003). In seaweeds, propagules are structures that become detached from the parental thallus, drift away and produce new established individuals (Hoffmann 1987, Macchiavello et al. 2003, HernándezCarmona et al. 2006, Stewart 2006, Sussmann \& DeWreede 2007, McKenzie \& Bellgrove 2008).

Unicellular entities (e.g., spores, gametes and zygotes) are the most common types of propagules in seaweeds, and have received considerable attention in the literature (e.g., Hoffmann 1987, Santelices 1990, Clayton 1992, Norton 1992, Reed et al. 1992, Kendrick \& Walker 1995, Gaylord et al. 2002, Opazo \& Otaíza 2007). In contrast, the importance of multicellular structures associated with vegetative reproduction is less frequently considered, despite the fact that breakage and drifting of thallus fragments may be a common dispersal mechanism for many seaweeds. Moreover, unicellular propagules have the capacity for primary attachment via the evacuation of adhesive vesicle contents, whereas drifting fragments may have different secondary attachment mechanisms, e.g., rhizoids (Pueschel 1990, Salinas 1991) or other secondary attachment structures (e.g., Otaíza \& Fonseca 2011).

Detachment and drifting of large fragments (e.g., sporophylls in some Laminariales) or even whole thalli carrying mature reproductive structures is frequent in macroalgae (Vásquez \& Tala 1995, Mathieson et al. 2003, Macaya et al. 2005, Hernández-Carmona et al. 2006, McKenzie \& Bellgrove 2008). While drifting, or once in contact with the substratum, these fragments may release spores or gametes, which are able to generate new individuals.

The release and dispersal of vegetative fragments can have important demographic effects. For example, fragments of Gracilaria chilensis are the main propagation structures for this species (Santelices \& Doty 1989, Buschmann et al. 1995). Drifting can also have important biogeographic effects. Floating kelp contribute to the connectivity of their populations and of associated organisms (Smith 2002, Hinojosa et al. 2010). Furthermore, fragmentation has favored the expansion of some nonindigenous algal invaders (Maggs \& Stegenga 1999) like Caulerpa taxifolia in Mediterranean and Australian waters (Ceccherelli \& Cinelli 1999, Smith \& Walters 1999 , Ceccherelli \& Piazzi 2001, Wright \& Davis 2006, Khou et al. 2007) and Codium fragile on Atlantic and Pacific coasts (Garbary et al. 2004). Indeed, invading species increase their chances of becoming established and expanding their populations when they have multiple types of propagules.

The genus Mastocarpus (Rhodophyta, Gigartinales) has several species on the northeastern Pacific coasts (Lindstrom et al. 2011). In contrast, a single species has been cited for the Chilean coasts (southeastern Pacific). Initially identified as Mastocarpus papillatus (C. Agardh) Kützing, the species present in Chile has been recently reassigned to Mastocarpus latissimus (Harvey) (see Lindstrom et al. 2011). This species is distributed from Alaska to southern California (Lindstrom et al. 2011) and is also very common around Concepción, south-central Chile (36 $45^{\circ}$ 'S; $73^{\circ} 03^{\prime}$ W; Santelices 1989, Hoffmann \& Santelices 1997, cited in both references as M. papillatus). This disjunct geographic distribution, together with a lack of congenerics in Chile and multiple congenerics present in Europe and Asia, occurrence in regions with potential vectors (e.g., international and national ports), and biological characteristics common in successful algal invaders like crustose growth form and ability for asexual reproduction (Hewitt et al. 2007, Carlton 2009), has lead to the proposal that this species is introduced on Chilean coasts (Castilla et al. 2005).

Species in the genus Mastocarpus have heteromorphic life-cycles in which crustose tetrasporophytes alternate with bladed gametophytes (Zupan \& West 1988, Lindstrom et al. 2011), although direct development of female gametophytes also occurs (Zupan \& West 1988, Fierst et al. 2010, Lindstrom et al. 2011). In the Mastocarpus populations present in Chile, blades grow from a perennial, crustose base to which they are attached by a narrow stipe (Hoffmann \& Santelices 1997). Reproductive, female gametophytic blades produce papillae which harbor the carposporophytes (Lindstrom et al. 2011). Unlike M. latissimus, male gametophytes are smooth, without papillae; given this discrepancy with the description given by Lindstrom et al. (2011), the species studied in this work will be referred to as Mastocarpus sp. For Mastocarpus species, only unicellular propagules (tetraspores and carpospores) have been described (e.g., West 1972, Polanshek \& West 1977, Zupan \& West 1988), although the possibility of detached blades playing a role in dispersal has been suggested (e.g., Carrington 1990). 
Preliminary observations indicate that the stipes of the blades and the peduncles of the papillae break off easily, even before many of the spores they bear are released (R. Otaíza, pers. observ.). The aim of this study is to evaluate the possibility that detachment of papillae and of blades carrying mature papillae may be important as an alternative dispersal mechanism of this species. We evaluated some detachment characteristics of blades and papillae, the occurrence of these structures drifting in the field, and the likelihood of spore release. We also evaluated whether there was a consistent pattern of papillae shedding along the blades in relation to their maturity, as a possible strategy to release papillae carrying viable spores.

\section{MAterials AND METHODS}

\section{STUdY SITES}

Fronds of Mastocarpus sp. were collected from three localities in south-central Chile: Península Hualpén (36 $46^{\circ}$ 'S; $\left.73^{\circ} 10^{\prime} \mathrm{W}\right)$, El Morro (36 $31^{\circ}$ 'S; $\left.73^{\circ} 57^{\prime} \mathrm{W}\right)$ and Coliumo ( $\left.36^{\circ} 31^{\prime} \mathrm{S} ; 72^{\circ} 57^{\prime} \mathrm{W}\right)$. All include moderately sheltered rocky shores where Mastocarpus sp. is abundant. The Petrocelis stage can be commonly found in most localities. Another site, Lenga $\left(36^{\circ} 45^{\prime} \mathrm{S} ; 73^{\circ} 10^{\prime} \mathrm{W}\right)$, was used to deploy some devices due to accessibility and protection offered by the Abate Juan Ignacio Molina Coastal Marine Laboratory (Universidad Católica de la Santísima Concepción).

\section{DisTRIBUTION OF PAPILLAE AND SCARS ALONG THE BLADES}

To determine the distribution of papillae along the blades, female blades were collected at Península Hualpén in April and May, 2007. In the laboratory, blades with a complete apex, were sorted according to the length of the longest axis into three size-categories: small $(5.0-6.9 \mathrm{~cm}$ in length), medium $(7.0-8.9 \mathrm{~cm})$ and large $(9.0-10.9 \mathrm{~cm})$. A total of 18 blades of each size-category were analyzed by cutting consecutive, $2 \mathrm{~cm}$ long segments, starting from the base and extending along the longest axis, resulting in 3, 4 or 5 segments, depending on the size-category.

Papillae were classified into two categories according to their size and development (Fig. 1). New papillae were up to $1 \mathrm{~mm}$ in length, with the base wider than the tip, and no distinguishable swelling of a developing carposporophyte inside. Old papillae were those with a narrow peduncule, presenting a distinguishable swelling resulting from the presence of developing carposporophytes. A third category included papillae that had broken off, identified as a circular scar on the blade surface or as the remains of the peduncle.

Figure 1. Surface of the blades of female (a-d) and male (e) gametophytes of Mastocarpus sp. Female gametophytes have new papillae (a) and old papillae (b). Papillae that have fallen off leave circular scars (arrowheads in c) or the remains of the peduncule of the papillae (arrowheads in d). Blade material collected at Lenga, March 2012. All photographs have the same scale bar: $5 \mathrm{~mm}$, included in (e) / Superficie de láminas de gametofitos femeninos (ad) y masculino (e) de Mastocarpus sp. Los gametofitos femeninos presentan papilas nuevas (a) y papilas viejas (b). El desprendimiento de papilas deja cicatrices circulares (cabezas de flecha en c) o los restos de los pedúnculos de las papilas (cabezas de flecha en d). Láminas colectadas en Lenga, marzo 2012. Todas las fotos tienen la misma barra de escala: $5 \mathrm{~mm}$, incluida en (e)
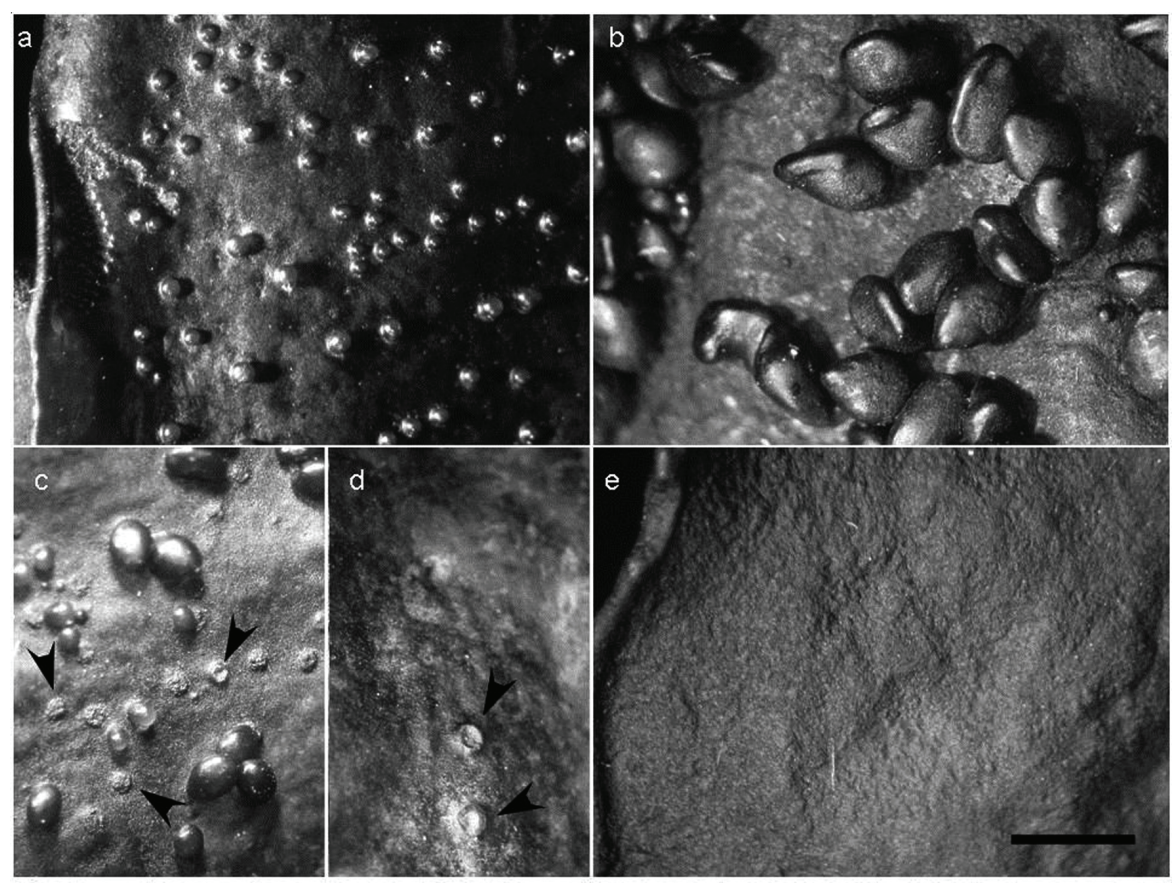
For each segment, the numbers of new and old papillae and scars were counted under a dissecting microscope, in two fields of view along each side of the blade. Values were averaged for each segment, separately for each type of reproductive structure. Data were standardized to one $\mathrm{cm}^{2}$. Density of new and old papillae and scars was analyzed separately for each frond size-category using an unreplicated randomized block ANOVA design, with Segment as the main factor and Blade as the block factor. To assure independence among density values in relation to blades, data for the blades of each size-category were randomly separated in three groups of six blades. Analyses for each of the three types of reproductive structures were done with data from one of these three groups of blades.

Cochran's test was used to evaluate the assumption of homogeneity of variances, and Shapiro-Wilk's test was used to evaluate the assumption of normality for all ANOVAs. Square-root or logarithmic transformations (Zar 1999) successfully corrected non-compliance with these assumptions when they occurred, and angular transformations corrected heterocedasticity of data expressed as proportions (see below). Significant differences detected by the analyses were explored with Tukey's HSD a posteriori test.

\section{DETACHMENT OF PAPILLAE IN LABORATORY CONDITIONS}

To evaluate whether detachment of papillae was related to blade length, blades were collected from El Morro between April and May, 2007, and sorted into the three blade size-categories. A fourth category, large tattered blades, included large blades (9.0-10.9 $\mathrm{cm}$ in length) whose apical portion was missing, indicating that these blades were originally longer than blades in the other categories. For each category, groups of blades were standardized to $5 \mathrm{~g}$, and the total number of old papillae in each group was counted. Three replicate groups of blades were used in each run of the experiment and sizecategory. Blade groups were placed in $500 \mathrm{~mL}$ graduated cylinders filled with seawater at $12 \pm 1{ }^{\circ} \mathrm{C}$. Double exit air pumps for aquaria were used to pump air into the graduated cylinders to produce moderate turbulence. After $24 \mathrm{~h}$, fronds were removed from the container and the detached papillae were counted. Each papilla was cut open to check for the presence of developing carposporophytes. The entire procedure was repeated on three occasions. The initial number of papillae and percentage of detached papillae relative to the initial number, were analyzed using two-way ANOVAs with Blade Size-category as a fixed effect factor, and Version of the Experiment as a random effect factor.

\section{DETACHMENT OF BLADES}

When collecting seaweeds in the field, the blades of Mastocarpus sp. detach more easily than those of other common red, intertidal seaweeds of similar size. To validate this observation we evaluated the force required to remove individual fronds of Mastocarpus sp. and two other common bladed red seaweeds, Mazzaella laminarioides and Nothogenia fastigiata, at Península Hualpén, in October 2006. For the three species, tested blades ranged between 10 and $15 \mathrm{~cm}$ in length. Blades of all species were sampled from the same patches (i.e., within $2 \mathrm{~m}$ ) on rocky surfaces with the same orientation, slope and exposure to wave action. To measure the force required to detach the blades, each blade was individually rolled, from the tip to about $3 \mathrm{~cm}$ from the base, onto a ballpoint pen casing, and fastened with clamps. The ends of this tube were attached to a $10 \mathrm{~N}$ dynamometer. Once secured, blades were pulled perpendicularly from the substratum with a steady force that produced detachment within about one second. Only cases in which breakage occurred from the base of the blades were recorded. For each species 100 trials were conducted. Results were compared using one-way ANOVA.

\section{DRIFTING PAPILlaE}

The occurrence of drifting papillae was assessed using trapping devices in the rocky intertidal zone at Lenga, where Mastocarpus sp. is present in dense patches. Each device consisted of a vertically oriented, $110 \mathrm{~mm}$ diameter, $40 \mathrm{~cm}$ long PVC tube, with a $1 \mathrm{~cm}$ mesh-covered top, closed at the bottom, and a lateral drainage window covered with $500 \mu \mathrm{m}$ mesh (Oróstica 2008). The upper end of the tube-trap was removable. It had a one-way entrance made of a 110-75 $\mathrm{mm}$ reducer coupling. The wider outer opening of the coupling was covered with a perforated cap (opening area: $78.5 \mathrm{~cm}^{2}$ ), which was covered with a plastic $1 \mathrm{~cm}$ mesh to prevent larger drifting seaweeds from being trapped or blocking the entrance. The narrower inner opening of the coupling was fitted with a mesh cone that worked as a one-way valve to prevent loss of the collected material. Devices were encased in aluminum strip harnesses and anchored to boulders in the low intertidal zone using bungee-cords. On three occasions between April and May, 2007, three devices were continuously deployed for two days. Collected material was sorted and papillae were counted. Of the local species, Mastocarpus sp. is the only one that has clearly pedunculated papillae; in other species, prominent cystocarps have a broad connection to the 
female thallus. As in the laboratory experiment, collected papillae were cut open to observe developing carposporophytes. The average of the daily mean number of positively identified papillae was compared to the null expectation of zero using Student's t-test.

\section{SPORE RELEASE BY DRIFTING BLADES}

Drifting Mastocarpus sp. blades were collected by hand from the water's edge along a $100 \mathrm{~m}$ transect parallel to the coast at Coliumo in March 2009. Only those with healthy appearance were collected and transported to the laboratory. To simulate the effect of desiccation at low tide, fronds were rinsed in seawater and exposed to air for $3 \mathrm{~h}$. Fronds were then placed individually in $400 \mathrm{~mL}$ storage dishes with filtered seawater and maintained, at $13 \pm 1^{\circ} \mathrm{C}$. After $24 \mathrm{~h}$, fronds were removed and water samples were checked for the presence of spores.

\section{Results}

\section{Distribution of PAPILlae AND SCARS ALONG The BLADES}

The density of new and old papillae and scars differed among blade segments, each presenting a distinct pattern. These trends were consistent among blades from the three size-categories. For new papillae, significant differences were found among segments for all size-categories (ANOVA Segment: $\mathrm{F}_{(2,10)}=9.32, P<0.0005 ; \mathrm{F}_{(3,15)}=8.43, P$ $<0.002 ; \mathrm{F}_{(4,20)}=17.43, P<0.0001$, for small, medium and large blades, respectively). For all size-categories, Tukey's tests indicated that new papillae were more abundant in the distal segment than the basal segment (Fig. 2). Thus, new papillae were most abundant close to the growing tip of the blade, and their density greatly decreased towards the older parts at the base of the blades.

Density of old papillae differed significantly among segments for medium and large blades (ANOVA Segment: $\mathrm{F}_{(3,15)}=4.05, P=0.027 ; \mathrm{F}_{(4,20)}=3.65, P=0.022$, for medium and large blades, respectively). For medium blades, Tukey's test indicated that only the highest density, obtained in the third segment, differed from the lowest density, found in the basal segment; other comparisons were not significant. For large blades, the density of old papillae was greater in the third and fourth segments than in the first, other comparisons were not significant. For small blades, the density of old papillae ranged from 37.2 $\pm 3.6 \mathrm{~cm}^{-2}$, in the basal segment, to $49.0 \pm 2.8 \mathrm{~cm}^{-2}$, in the second segment, but no differences among segments were found (ANOVA Segment: $\mathrm{F}_{(2,10)}=2.19, P=0.16$ ).
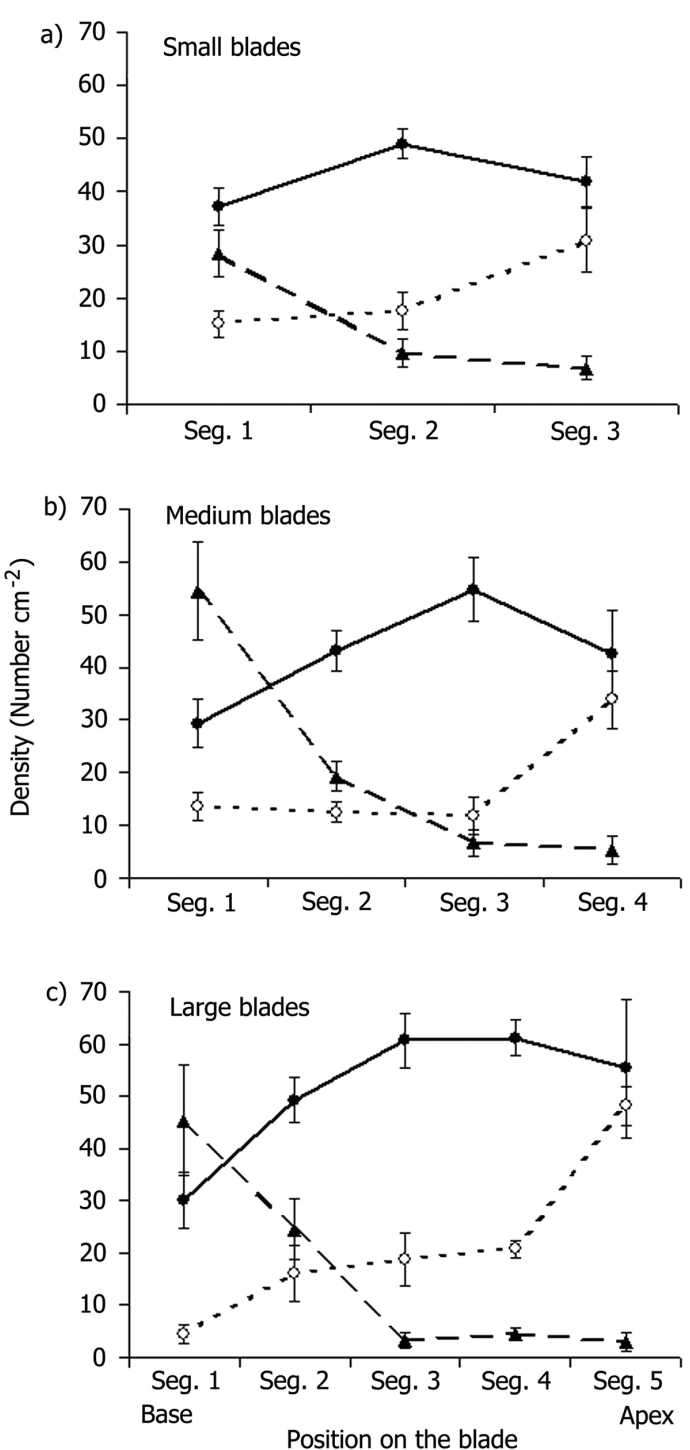

Figure 2. Mean density ( \pm standard error) of new papillae (open circles, dotted line) and old papillae (full circles, continuous line) and scars left by shed papillae (triangles, dashed line) on blades of Mastocarpus sp. Whole blades (i.e., with an intact apex): a) small blades (5.0-6.9 cm in length), b) medium blades (7.0-8.9 $\mathrm{cm})$ and c) large blades $(9.0-10.9 \mathrm{~cm})$, considering six different blades for each stage of development of the reproductive structures. Blade segments: Seg. 1 (basal) to Seg. 5 (apical in large blades) / Densidad promedio ( \pm error estándar) de papilas nuevas (círculos abiertos, línea punteada) y papilas viejas (círculos cerrados, línea continua) y cicatrices dejadas por papilas desprendidas (triángulos, línea segmentada) en láminas de Mastocarpus sp. Láminas completas (i.e., con un ápice intacto): a) láminas pequeñas (5,0-6,9 cm en longitud), b) láminas medianas $(7,0-8,9 \mathrm{~cm}), y \mathrm{c})$ láminas grandes $(9,0-10,9 \mathrm{~cm})$, considerando seis láminas diferentes para cada estado de desarrollo de las estructuras reproductivas. Segmentos en la lámina: Seg. 1 (basal) a Seg. 5 (apical de las láminas grandes) 
Thus, for the two larger blade size-categories, old papillae reach maximum density at a short distance from the apex, and decrease in abundance towards the oldest parts of the blade.

The density of scars differed significantly among segments for all blade size-categories (ANOVA Segment: $\mathrm{F}_{(2,10)}=11.17, P<0.003 ; \mathrm{F}_{(3,15)}=21.03, P<0.0001, \mathrm{~F}_{(4,20)}=$ 23.57, $P<0.0001$, for small, medium and large blades, respectively). Tukey's tests indicated that the density of scars was significantly greater in the basal segment than in the two more distal segments in all size-categories. While scars could be found on small blades, the greatest values were observed in the two most basal segments of medium and large blades, and were scarcely present in the apical segments.

\section{Detachment of Papillae Under laboratory CONDITIONS}

The detachment of papillae under experimental conditions in the laboratory was evaluated in four blade sizecategories. The initial number of papillae only showed a significant effect of blade size-category (ANOVA $\mathrm{F}_{(3,6)}=$ 25.98, $P<0.0008)$. Tukey's test indicated that all four means differed from each other. The initial number of papillae was lower in small blades, ranging between 1023 and 1970 in $5 \mathrm{~g}$ of fresh blade tissue, and was highest in the large tattered blades, ranging from 2503 to 3061 in $5 \mathrm{~g}$ of blades, while medium and large whole blades had intermediate values (1845 to 2531 and 2150 to 2748 , respectively). After $24 \mathrm{~h}$ of exposure to turbulence in the laboratory, between one and 24 papillae became detached in each replicate of every treatment, representing between 0.05 and $0.93 \%$ of the papillae initially present in those replicates. There were no significant differences between the proportion of papillae shed from fronds of different size-categories (ANOVA $\mathrm{F}_{(3,6)}=4.002, P=0.07$ ), with an overall average of $0.33 \pm 0.06$ in $5 \mathrm{~g}$ of blade tissue. The interaction term was also non-significant (ANOVA $\mathrm{F}_{(6,24)}$ $=1.857, P=0.13)$, but there were differences among repeats of the experiment $\left(\mathrm{ANOVAF}_{(2,24)}=4.805, P=0.03\right)$; Tukey's test indicated that there were significant differences between the first and the third repeat of the experiment, revealing some variation between fronds collected on different days. In all cases the shed papillae had intact pericarps, indicating that spores had not been released. Dissection of these papillae showed that all contained developing carposporophytes with pigmented spores.

\section{DETACHMENT OF BLADES}

The force required to detach blades of Mastocarpus sp. was $4.0 \pm 0.13 \mathrm{~N}$, which was significantly lower (ANOVA $\left.\mathrm{F}_{(2,291)}=176.32, P<0.001\right)$ than that required to detach blades of Mazzaella laminarioides or Nothogenia fastigiata ( $8.5 \pm 0.19$ and $7.7 \pm 0.26 \mathrm{~N}$, respectively). Detachment of blades of Mastocarpus sp. always occurred at the narrowest part of the blades, where the fronds emerge from the basal crust. In contrast, for the other two species, blades sometimes broke at more distal parts; as explained above, these values were not included in the analysis.

\section{DrifTING PAPILlaE}

The devices were effective in trapping drifting papillae of Mastocarpus sp. Although the number of papillae found was not large, all traps collected between one and five papillae in two days, on each of the three occasions that they were employed, with a mean number of $2.0 \pm 0.19$ papillae in $78.5 \mathrm{~cm}^{-2}$ entrapment area over the two-day period. This average number of papillae was significantly different from zero $(\mathrm{t}=11.55, \mathrm{n}=3, P=0.004)$. Of the papillae trapped in the collecting devices, all contained at least one developing carposporophyte with normally pigmented spores.

\section{SPORE RELEASE BY DRIFTING BLADES}

Blades of Mastocarpus sp. are common and easily collected among drift algae. Blades with normal, fresh appearance were abundant. A total of 53 healthy Mastocarpus sp. blades were collected. In the laboratory, all of the collected blades released spores with normal appearance and pigmentation.

\section{Discussion}

The establishment and expansion of an invading species can be facilitated by the occurrence of multiple dispersing entities (Khou et al. 2007). Our results suggest that blades and papillae of Mastocarpus sp. could be considered as alternative dispersing structures to spores because they not only detach easily, but they do so when carposporophytes still have spores that could eventually be released. Further studies should determine the ability of such spores to settle and germinate.

Our results indicate that blades of Mastocarpus sp. required less force for removal from the rocky surface than two other common, similarly sized, intertidal 
seaweeds, namely Mazzaella laminarioides and Nothogenia fastigiata. The values of detachment force found here were similar to values reported for Mastocarpus elsewhere (see Thomsen \& Wernberg 2005). The relatively weaker attachment of Mastocarpus sp. may result in greater blade loss, with a potentially negative effect on the reproductive potential of the individuals. One possible consequence of blade detachment is a change in the population size structure. Carrington (1990) found that there was no increase in the cross-sectional area of stipes with increasing thallus area in M. papillatus. Given that drag on the thallus increased with size, there was greater detachment of larger blades at sites with more wave exposure, which affected the size distribution of blades within this species. Blade detachment due to hydrodynamic forces could also affect reproductive potential, as suggested by Denny \& Wethey (2001). Differential detachment of larger blades has also been used to explain differences in abundance between species along a wave exposure gradient. Shaughnessy et al. (1996) found that Mazzaella linearis was abundant at sites with high wave exposure, while Mazzaella splendens was more abundant at less exposed sites. They explain this pattern through morphological and biomechanical differences between the two species. Dudgeon \& Johnson (1992) also used mechanical and morphological characteristics in relation to hydrodynamic forces to explain coexistence in mixed stands of Chondrus crispus and Mastocarpus stellatus. On the other hand, blade detachment can also have a positive effect on the population. In our study, the proportion of blades that broke off from the rocks was not evaluated, but breakage of blades carrying reproductive structures could be frequent, as suggested by the occurrence of Mastocarpus sp. in material from the drift line. All of the drifting blades that were tested released spores, indicating that they still had reproductive potential and, therefore, did not represent senescent tissue that had been abscised. Thus, detached and drifting mature blades may act as dispersing entities. Dispersal by entire blades has been suggested before for $M$. papillatus and for other species (Hoffmann 1987, Carrington 1990, Santelices 1990, Norton 1992, Blanchette 1997, Pratt \& Johnson 2002).

Not only do mature blades become detached, but mature papillae on the blades also detached when subjected to a moderate turbulence. In the field, observations indicate that some papillae easily fall off simply by touching blades that have been partly desiccated during low tides (R. Otaíza, pers. observ.). The number of papillae that became detached in laboratory experiments was not high. However, if the daily losses are projected linearly, the accumulated number of shed papillae could be considerable, representing an estimated monthly loss of $14.9 \%$ of papillae for the largest blades. Moreover, desiccation and wave action conditions in the field could enhance breakage of peduncles, favoring papillae detachment.

Drifting papillae were also collected in the field. These evaluations were aimed to demonstrate that drifting papillae do occur in the field. The traps were successful in capturing papillae, although their abundance was low. Nevertheless, a linear projection of the average number of papillae collected in the traps would result in over 3000 papillae $\mathrm{m}^{-2} \mathrm{mo}^{-1}$. If the shedding of papillae represents the elimination of structures that have completed their functional period of hosting carposporophytes, it would be expected to occur after the carpospores were released. Nevertheless, this seems not to be the case, given that all the papillae detached in the laboratory experiment, and also those collected in the traps, contained carposporophytes with well-pigmented spores. Although no germination or spore-viability tests were done, their normal appearance and pigmentation suggested that the spores were viable. In this sense, detachment of papillae carrying apparently viable spores could initially be interpreted as a loss of reproductive potential for individuals, but may result in dispersal if they are capable of releasing spores while drifting away from the parental thallus, or once they come in contact with the substratum. Thus, as with detached whole blades, drifting papillae may also act as important dispersing entities.

In order for blades and papillae to be considered as dispersing structures, there should be a mechanism that produces their detachment at an appropriate moment. Our study shows that the detachment of blades of Mastocarpus sp. occurred mainly at the narrow base of the stipe. Other studies show similar results for $M$. papillatus (Carrington 1990, Kitzes \& Denny 2005) and for Mazzaella splendens and Mazzaella linearis (Shaughnessy et al. 1996). Some morphological features may facilitate the detachment of blades and papillae at their bases, particularly as they grow and mature. On one hand, allometric growth results in an increase in drag forces acting on the blades, facilitating their detachment. Greater planform area has been associated with greater drag force, so it is expected that dislodgment is facilitated as blades grow (Carrington 1990, Dudgeon \& Johnson 1992, Kitzes \& Denny 2005). Also, it has been shown that 
the presence of structures on the surface of the blades results in increased drag (Carrington 1990). As blades of Mastocarpus spp. mature, papillae carrying carposporophytes are produced on the surface as a consequence of sexual reproduction, and as blades grow, the number of papillae increases (West 1972, Polanshek \& West 1977, Carrington 1990, Lindstrom et al. 2011). On the other hand, as blades grow, their detachment is further facilitated by features that result in the weakening of the attachment points. Cross-sectional area of the stipes may either not increase (e.g., M. papillatus; Carrington 1990), or may increase only slightly (e.g., Mastocarpus stellatus; Dudgeon \& Johnson 1992, Pratt \& Johnson 2002), in both cases resulting in a negative allometric relationship with blade area. Hence, the union of the blades to basal structures becomes relatively weaker as blades grow. Moreover, it has been shown for M. stellatus that tissue strength decreases with increased stipe cross-sectional area (Dudgeon \& Johnson 1992). Therefore, as blades grow and mature, an increase in drag is expected, while the weaker parts of the stipes do not increase proportionately in strength, thus resulting in greater chances of becoming detached. A similar case was described for Turbinaria ornata in which fronds become mature, more buoyant and break off, resulting in their dispersal throughout French Polynesia (Stewart 2006).

Detachment of papillae can be explained by a similar mechanism. Papillae on the surface of a blade grow and swell as carposporophytes develop while their basal portion remains a narrow peduncle. This size increase of papillae will increase drag (Carrington 1990) and, in turn, increase the chances of papillae detachment. Thus, detached papillae are expected to be the oldest, mature papillae. This is supported by our results. First, results of the laboratory experiments indicated that the shed papillae were mature papillae containing spores. Second, the pattern of distribution of new and old papillae, and scars, differed along the blades. While new papillae were more abundant on the apical, younger segments, and mature papillae were more abundant on the middle segments, scars of shed papillae were more abundant at the base of the blades (Fig. 2). Also, scars were more abundant on large and mid-sized blades than on the smaller blades (Fig. 2). These results show a distinctive release pattern, where shed papillae were the oldest ones, occurring on the oldest parts of the blades.

In this species, the chances of blades and papillae becoming detached from the parental thallus and drifting away increase with the size of the structure, and consequently, the maturity of the carposporophytes they carry. Also, both papillae and blades with papillae can release spores and, thus, may have the potential to produce new individuals. Therefore, both blades and papillae can be considered as propagules, representing dispersing structures in addition to tetraspores and carpospores. Mastocarpus sp. is a proposed invader in Chile (Castilla et al. 2005). While the moment and locality of arrival or the vector transporting this species to Chile are not known with precision (Castilla et al. 2005), we propose that having additional dispersing entities alternative to spores may have favored its establishment and subsequent expansion.

Dispersing entities that are structurally very different from spores may represent advantages for dispersal in several ways. One advantage is that dispersal trajectories and arrival sites of these structures may be different from those of spores. Blades and papillae differ from spores in their buoyancy, so it is expected that once detached, they will sink to the subtidal zone and be subject to currents there. Spores, on the other hand, will most likely remain suspended in the water column (Gaylord et al. 2002, Opazo \& Otaíza 2007) and be transported by more superficial water currents. Hence, the release or detachment of different types of structures may result in the transport of propagules to, and the colonization of, different habitats. Furthermore, blades or papillae may also release spores while drifting. A second advantage of additional dispersing entities is that these multicellular structures may undergo considerable dispersal distances before they release spores. Extreme cases include the long distance, trans-oceanic transport reported for some kelps and fucoids (Hobday 2000, Thiel 2003, Macaya et al. 2005, Thiel \& Gutow 2005, Stewart 2006, McKenzie \& Bellgrove 2008), but local transport by nearshore currents may be a much more frequent means of dispersal. In contrast, the short viability period of spores released by the attached parental thalli limits the distance that they can effectively disperse (Norton 1992, Bobadilla \& Santelices 2004, 2005). A third advantage is that spores inside these multicellular dispersing structures should have reduced mortality while drifting in the water column given that they are protected and nourished by the adult tissue (Hommersand \& Fredericq 1990). Unicellular entities, such as spores, released singly or in gelatinous matrices are at high mortality risk in the water column and on the substrata once they settle (Santelices 1990, Amsler et al. 1992). Finally, upon arrival to the shore, a multicellular entity may release a mass of spores onto a hard substratum. 
Groups of spores in close proximity may coalesce and produce a single new individual (Santelices et al. 1999). As a consequence, an individual growing from a group of spores will attain a larger size more rapidly than one that grows from a single spore. This should reduce mortality related to small size, particularly at the germling stage (Santelices \& Alvarado 2008).

Our results show that blades and papillae have features that facilitate their breakage from the parental thallus as they grow and mature. This does not represent abscission of empty or senescent structures. Instead, these structures may actually be important in facilitating the establishment of new individuals at distances and places that may be different from what is achieved by spores. Hence, they could be considered as alternative dispersing entities (Carrington 1990, Blanchette 1997, Pratt \& Johnson 2002). To better understand the population dynamics and range expansion of Mastocarpus sp. in Chile, it is necessary to determine the success and relative contribution of each of these dispersing entities to the population.

\section{ACKNOWLEDGMENTS}

This research was done as part of the Marine Biology undergraduate thesis requirements (U. Católica SSMA. Concepción, Chile) of MO. MO thanks the Centro Regional de Investigación y Desarrollo Sustentable de Atacama (CRIDESAT) for support during the writing of this work. We thank P. Veas and R. Soto-Benavides for help in the field. The authors are grateful to suggestions by anonymous reviewers which greatly improved this manuscript.

\section{LITERATURE CITED}

Amsler C, D Reed \& M Neushul. 1992. The microclimate inhabited by macroalgal propagules. British Phycological Journal 27: 253-270.

Blanchette CA. 1997. Size and survival of intertidal plants in response to wave action: A case study with Fucus gardneri. Ecology 78: 1563-1578.

Bobadilla M \& B Santelices. 2004. New technique for simultaneous collection of macroalgal propagules in the water column. Journal of Experimental Marine Biology and Ecology 298: 125-131.

Bobadilla M \& B Santelices. 2005. Variations in the dispersal curves of macroalgal propagules from a source. Journal of Experimental Marine Biology and Ecology 327: 47-57.
Buschmann AH, R Westermeier \& C Retamales. 1995. Cultivation of Gracilaria in the sea-bottom in southern Chile: a review. Journal of Applied Phycology 7: 291-301.

Carlton JT. 2009. Deep invasion ecology and the assembly of communities in historical time. In: Rilov G \& JA Crooks (eds). Biological invasions in marine ecosystems, pp. 1356. Springer-Verlag, Berlin.

Carrington E. 1990. Drag and dislodgment of an intertidal macroalga: consequences of morphological variation in Mastocarpus papillatus Kützing. Journal of Experimental Marine Biology and Ecology 139: 185-200.

Castilla JC, M Uribe, N Bahamonde, M Clarke, R Desqueyroux-Faúndez, I Kong, H Moyano, N Rozbaczylo, B Santelices, C Valdovinos \& P Zavala. 2005. Down under the Southeastern Pacific: marine non-indigenous species in Chile. Biological Invasions 7: 213-232.

Ceccherelli G \& F Cinelli. 1999. The role of vegetative fragmentation in dispersal of the invasive alga Caulerpa taxifolia in the Mediterranean. Marine Ecology Progress Series 182: 299-303.

Ceccherelli G \& L Piazzi. 2001. Dispersal of Caulerpa racemosa fragments in the Mediterranean: lack of detachment time effect on establishment. Botanica Marina 44: 209-213.

Clayton M. 1992. Propagules of marine macroalgae: structure and development. British Phycological Journal 24: 219-232.

Denny M \& D Wethey. 2001. Physical processes that generate patterns in marine communities. In: Bertness MS, SD Gaines \& M Hay (eds). Marine community ecology, pp. 3-37. Sinauer Associates, Massachusetts.

Dudgeon SR \& AS Johnson. 1992. Thick vs. thin: thallus morphology and tissue mechanics influence differential drag and dislodgment of two co-dominant seaweeds. Journal of Experimental Marine Biology and Ecology 165: 23-43.

Fierst JL, JE Kübler \& SR Dudgeon. 2010. Spatial distribution and reproductive phenology of sexual and asexual Mastocarpus papillatus (Rhodophyta). Phycologia 49: 274-282.

Gaylord B, DC Reed, PT Raimondi, L Washburn \& SR McLean. 2002. A physically based model of macroalgal spore dispersal in the wave and current-dominated nearshore. Ecology 83: 1239-1251.

Garbary DJ, SJ Fraser, C Hubbard \& KY Kim. 2004. Codium fragile: rhizomatous growth in the Zostera thief of eastern Canada. Helgoland Marine Research 58: 141-146.

Hernández-Carmona G, B Hughes \& MH Graham. 2006. Reproductive longevity of drifting kelp Macrocystis pyrifera (Phaeophyceae) in Monterey Bay, USA. Journal of Phycology 42: 1199-1207.

Hewitt CL, ML Campbell \& B Schaffelke. 2007. Introductions of seaweeds: accidental transfer pathways and mechanisms. Botanica Marina 50: 326-337. 
Hinojosa IA, M Pizarro, M Ramos \& M Thiel. 2010. Spatial and temporal distribution of floating kelp in the channels and fjords of southern Chile. Estuarine Coastal and Shelf Science 87: 367-377.

Hobday AJ. 2000. Persistence and transport of fauna on drifting kelp (Macrocystis pyrifera (L.) C. Agardh) rafts in the Southern California Bight. Journal of Experimental Marine Biology and Ecology 253: 75-96.

Hoffmann AJ. 1987. The arrival of seaweed propagules at the shore: a review. Botanica Marina 30: 151-165.

Hoffmann A \& B Santelices. 1997. Flora marina de Chile central, 434 pp. Ediciones Universidad Católica de Chile, Santiago.

Hommersand MH \& S Fredericq. 1990. Sexual reproduction and cystocarp development. In: Cole KM \& RG Sheath (eds). Biology of the red algae, pp. 305-345. Cambridge University Press, Cambridge.

Kendrick GA \& DI Walker. 1995. Dispersal of propagules of Sargassum spp. (Sargassaceae: Phaeophyta): Observations of local patterns of dispersal and consequences for recruitment and population structure. Journal of Phycology 195: 273-288.

Khou M, NA Paul, JT Wright \& PD Steinberg. 2007. Intrinsic factors influence the attachment of fragments of the green alga Caulerpa filiformis. Journal of Experimental Marine Biology and Ecology 352: 331-342.

Kinlan BP \& SD Gaines. 2003. Propagule dispersal in marine and terrestrial environments: a community perspective. Ecology 84: 2007-2020.

Kitzes JA \& M Denny. 2005. Red algae respond to waves: Morphological and mechanical variation in Mastocarpus papillatus along a gradient of force. The Biological Bulletin 208: 114-119.

Lindstrom SC, JR Hughey \& PT Martone. 2011. New, resurrected and redefined species of Mastocarpus (Phyllophoraceae, Rhodophyta) from the northeast Pacific. Phycologia 50: 661-683.

Macaya EC, S Boltana, IA Hinojosa, JE Macchiavello, NA Valdivia, NR Vasquez, AH Buschmann, JA Vásquez, JMA Vega \& M Thiel. 2005. Presence of sporophylls in floating kelp rafts of Macrocystis spp. (Phaeophyceae) along the Chilean pacific coast. Journal of Phycology 41: 913-922.

Macchiavello J, C Bulboa \& M Edding. 2003. Vegetative propagation and spore-based recruitment in the carrageenophyte Chondracanthus chamissoi (Gigartinales, Rhodophyta) in northern Chile. Phycological Research 51: 45-50.

Maggs CA \& H Stegenga. 1999. Red algal exotics of North Sea coasts. Helgoländer Meeresuntersuchungen 52: 243-258.

Mathieson AC, CJ Dawes, LG Harris \& EJ Hehre. 2003. Expansion of the Asiatic green alga Codium fragile ssp. tomentosides in the Gulf of Maine. Rhodora 105: 1-53.
McKenzie PF \& A Bellgrove. 2008. Dispersal of Hormosira banksii (Phaeophyceae) via detached fragments: reproductive viability and longevity. Journal of Phycology 44: 1108-1115.

Norton T. 1992. Dispersal by macroalgae. British Phycological Journal 27: 293-301.

Opazo FL \& RD Otaíza. 2007. Vertical distribution of spores of blade-forming Sarcothalia crispata (Gigartinaceae) and crustose corallines (Corallinaceae) in the water column. Botanica Marina 50: 97-105.

Oróstica MH. 2008. Estructuras alternativas de dispersión y abundancia del alga intermareal Mastocarpus papillatus (C. Agardh) Kützing (Rhodophyta, Petrocelidaceae). Tesis Biología Marina, Facultad de Ciencias, Universidad Católica de la Santísima Concepción, Concepción, 59 pp.

Otaíza RD \& FG Fonseca. 2011. Effect of dissolved calcium on the formation of secondary attachment structures in different types of branches of Chondracanthus chamissoi (Rhodophyta, Gigartinales). Revista de Biología Marina y Oceanografía 46: 263-268.

Polanshek AR \& JA West. 1977. Culture and hybridization studies on Gigartina papillata (Rhodophyta). Journal of Phycology 13: 141-149.

Pratt MC \& AS Johnson. 2002. Strength, drag, and dislodgment of two competing intertidal algae from two wave exposures and four seasons. Journal of Experimental Marine Biology and Ecology 272: 71-101.

Pueschel CM. 1990. Cell structure. In: Cole KM \& RG Sheath (eds). Biology of the red algae, pp. 7-41. Cambridge University Press, Cambridge.

Reed DC, CD Amsler \& A Ebeling. 1992. Dispersal in kelps: factors affecting spore swimming and competency. Ecology 73: 1577-1585.

Reed DC, PT Raimondi, MH Carr \& L Goldwasser. 2000. The role of dispersal and disturbance in determining spatial heterogeneity in sedentary organisms. Ecology 81: 20112026.

Salinas JM. 1991. Spray system for re-attachment of Gelidium sesquipedale (Clem.) Born. et Thur. (Gelidiales: Rhodophyta). Hydrobiologia 221: 107-117.

Santelices B. 1989. Algas marinas de Chile, 399 pp. Ediciones Universidad Católica de Chile, Santiago.

Santelices B. 1990. Patterns of reproduction, dispersal and recruitment in seaweeds. Oceanography and Marine Biology: An Annual Review 28: 117-276.

Santelices B \& JLAlvarado. 2008. Demographic consequences of coalescence in sporeling populations of Mazzaella laminarioides (Gigartinales, Rhodophyta). Journal of Phycology 44: 624-636.

Santelices B \& MS Doty. 1989. A review of Gracilaria farming. Aquaculture 78: 95-133. 
Santelices B, JA Correa, D Aedo, V Flores, M Hormazábal \& P Sánchez. 1999. Convergent biological processes in coalescing Rhodophyta. Journal of Phycology 35: 11271149.

Shanks AL, BA Grantham \& MH Carr. 2003. Propagule dispersal distance and the size and spacing of marine reserves. Ecological Applications 13: 159-169.

Shaughnessy FJ, RE DeWreede \& EC Bell. 1996. Consequences of morphology and tissue strength to blade survivorship of two closely related Rhodophyta species. Marine Ecology Progress Series 136: 257-266.

Smith CM \& LJ Walters. 1999. Fragmentation as a strategy for Caulerpa species: fates of fragments and implications for management of an invasive weed. Marine Ecology 20: 307-319.

Smith SDA. 2002. Kelp rafts in the Southern Ocean. Global Ecology and Biogeography 11: 67-69.

Stewart HL. 2006. Ontogenetic changes in buoyancy, breaking strength, extensibility, and reproductive investment in a drifting macroalga Turbinaria ornata (Phaeophyta). Journal of Phycology 42: 43-50.

Sussmann AV \& RE DeWreede. 2007. Relative contribution of vegetative propagation and sexual reproduction in the maintenance of Acrosiphonia (Chlorophyta) populations. Phycologia 46: 79-85.
Thiel M. 2003. Rafting of benthic macrofauna: important factors determining the temporal succession of the assemblage on detached macroalgae. Hydrobiologia 503: 49-57.

Thiel M \& L Gutow. 2005. The ecology of rafting in the marine environment. II. The rafting of organisms and community. Oceanography and Marine Biology: An Annual Review 43: 279-418.

Thomsen MS \& T Wernberg. 2005. Miniview: What affects the forces required to break or dislodge macroalgae? European Journal of Phycology 40: 139-148.

Vásquez JA \& F Tala. 1995. Repopulation of intertidal areas with Lessonia nigrescens in northern Chile. Journal of Applied Phycology 7: 347-349.

West JA. 1972. The life history of Petrocelis franciscana. British Phycological Journal 7: 299-308.

Wright JT \& AR Davis. 2006. Demographic feedback between clonal growth and fragmentation in an invasive seaweed. Ecology 87: 1744-1754.

Zar JH. 1999. Biostatistical analysis, 663 pp. Prentice Hall, Englewood Cliffs.

Zupan JR \& JA West. 1988. Geographic variation in the life history of Mastocarpus papillatus (Rhodophyta). Journal of Phycology 24: 223-229.

Received 16 December 2011 and accepted 19 March 2012 